\title{
Efficacy of Bacterial Strains Isolated from Textile Wastewater for Degradation of Azo Dye Associated Aromatic Amines
}

\author{
Farzana Kausar $^{1}$, Azeem Khalid ${ }^{1 *}$, Tariq Mahmood ${ }^{1}$ and Nosheen Ilyas ${ }^{2}$ \\ ${ }^{1}$ Department of Environmental Sciences, PMAS Arid Agriculture University, Rawalpindi, Pakistan \\ ${ }^{2}$ Department of Botany, PMAS Arid Agriculture University, Rawalpindi, Pakistan \\ *For correspondence: azeem@uaar.edu.pk; azeemuaf@yahoo.com
}

\begin{abstract}
Wastewater from textile processing and dyestuff manufacturing industries contains different kinds of dyes and their metabolites, which are mutagenic and carcinogenic in nature. Such wastewater should be treated in order to avoid ground and surface water contamination. The aim of present research was to isolate such bacterial strains which are capable of degrading dye-originated aromatic amines. Ten samples of wastewater and sludge were collected from outlets and wastewater streams of different textile industries. The analysis of wastewater showed a wide variation in the $\mathrm{pH}(8.10-12.3)$, total dissolved solids (500-20100 mg L-1) and chemical oxygen demand (125-556 $\left.\mathrm{mg} \mathrm{L}^{-1}\right)$. A total of 256 bacterial isolates were collected through enrichment of the mineral salt medium with an aromatic amine, 4-nitroaniline $\left(100 \mu \mathrm{mol} \mathrm{L}^{-1}\right)$, and dyes $\left(100 \mathrm{mg} \mathrm{L}^{-1}\right) \mathrm{using} 10$ $\mathrm{mL}$ wastewater/sludge as inoculum source. Based on ability to degrade 4-nitroaniline most efficient bacterial strain was identified as Raoultella planticola (IL11) through 16S rRNA gene analysis. These findings suggest that the indigenous bacterial strains have potential for bioremediation of dye-containing textile effluents, and for complete mineralization, 4nitroaniline degrading strains may be used in combination with dye degrading strains. (C) 2016 Friends Science Publishers
\end{abstract}

Keywords: Azo dyes; Aromatic amines; Wastewater; Biodegradation; Bacteria

\section{Introduction}

Dyes are used in textile sector on large scale among which azo dyes constitute more than $50 \%$ of total dye production worldwide (Meng et al., 2012). Inefficient textile dyeing process results in the release of large amount of dyes in effluent which is directly discharged into the water bodies (Khalid et al., 2011; Mahmood et al., 2011; Kurade et al., 2016; Rawat et al., 2016). About 10-15\% of dyestuff is discharged into environment during manufacturing and usage of these dyes (Verma and Madamwar, 2002; Andleeb et al., 2010). Textile finishing process requires an average amount of 100,000-150,000 L of water, as a result of which large amount of dyes residues are released in to the environment (Bezerra, 2005). Even very small quantity of the dye (less than $1 \mathrm{mg} \mathrm{L}^{-1}$ for some dyes) is clearly visible in water and does not only affect aesthetic quality but also affect oxygen solubility in water bodies.

The wastewater produced by the textile industry contains dyes and their residues, which cannot be treated by conventional treatment methods (Kangwansupamonkon et al., 2010; Aravind et al., 2016). Such wastewaters are known as carcinogenic and mutagenic and have toxic effects on aquatic organisms including fish, algae and other aquatic fauna (Annuar et al., 2009). Also the dye wastewater has variable range of $\mathrm{BOD}, \mathrm{COD}, \mathrm{pH}$, color and salts (Peyton et al., 2002; Seesuriyachan et al., 2007). Untreated dye wastewater, which is used for different purposes such as agriculture has serious harmful impacts on human health (Pourbabaee et al., 2006). Carcinogenicity, mutagenicity and toxicity of dyes and their metabolites has increased the health concerns over the period of time. Dye degradation in most of cases take place under anaerobic conditions. These anaerobically decolorized dye effluents are still harmful as it contains colorless aromatic amines and many of these metabolites are carcinogenic and mutagenic in nature. It has been observed that azo dyes can reduce into aromatic amines in the digestive tract of mammals (Chung et al., 1992). Study conducted by Xu et al. (2007) confirmed that biological reduction of Para Red and Sudan dyes by human intestinal microbes leads to production of various aromatic amines such as aniline, 2,4-dimethylaniline, o-toluidine and p-nitroaniline. These amines are easily absorbed by the human intestine and cause toxicity (Bomhard and Herbold, 2005; Wu et al., 2005). It is most likely that the textile wastewater could be highly toxic to the environment especially when groundwater is getting contaminated and further used for drinking purposes. In developing countries such as Pakistan, the dye-contaminated water in urban and suburban areas are also used for growing vegetables and other crops, which represent a high health risk for people living in the vicinity of textile industry. 
In view of the above, it is imperative to develop a strategy not only for the degradation of dyes but also their intermediate colorless products that are highly toxic to the environment. For this purpose, several strains of bacteria were isolated form textile wastewater and sludge and screened for efficient degradation of aromatic amine, 4nitroaniline. The selected strains could be used for developing strategy for treating textile wastewater before being its discharge into the environment.

\section{Materials and Methods}

\section{Chemicals and Culture Medium}

The 4-nitroaniline was used for the isolation of bacteria capable of degrading dye originated aromatic compounds. Similarly three types of structurally different four azo dyes Reactive Black 5, Reactive Blue BRS, Direct Blue and Disperse Yellow were used for enrichment of the medium to isolate bacteria. Mineral salts medium (MSM) containing (g $\left.\mathrm{L}^{-1}\right) \mathrm{NaCl}(1.0), \mathrm{CaCl}_{2} .2 \mathrm{H}_{2} \mathrm{O}(0.1), \mathrm{MgSO}_{4} .7 \mathrm{H}_{2} \mathrm{O}(0.5)$, $\mathrm{KH}_{2} \mathrm{PO}_{4}$ (1.0), $\mathrm{Na}_{2} \mathrm{HPO}_{4}$ (1.0) and yeast extract (4.0) was used for isolation of bacterial strains through enrichment technique (Khalid et al., 2008). The $\mathrm{pH}$ of the medium was adjusted to 7.2. All chemicals used in the experiments were of AR grade.

\section{Collection of Wastewater/Sludge Samples}

Ten samples of wastewater and/or sludge were obtained from wastewater streams of the textile industry in three districts (Rawalpindi, Faisalabad and Sheikhupura) in the province of Punjab, Pakistan. Textile processing units are widespread in the district Faisalabad (situated at latitude $31.43^{\circ} \mathrm{N}$ and longitude $\left.72.07^{\circ} \mathrm{E}\right)$ and Sheikhupura $\left(31.72^{\circ}\right.$ $\mathrm{N} 72.98^{\circ} \mathrm{E}$ ), while a large processing unit is located in the district of Rawalpindi $\left(36.60^{\circ} \mathrm{N} 73.03^{\circ} \mathrm{E}\right)$. Five wastewater samples were obtained from Faisalabad textile factories. Three samples were collected from the waste streams of textile units in Sheikhupura. Two samples were obtained from a textile factory in Rawalpindi. All samples were collected in sterile $50 \mathrm{~mL}$ Falcon tubes and stored at $4^{\circ} \mathrm{C}$ prior to use.

\section{Analysis of Wastewater}

The wastewater and sludge samples were analyzed for color intensity, $\mathrm{pH}$, total dissolved solids (TDS) and chemical oxygen demand (COD). Dye levels in colored wastewater were determined by spectrophotometer (Modified MA 02052-USA) at $600 \mathrm{~nm}$. Since different types of dyes are used by the textile industry therefore, so $\mathrm{pH}$ and TDS of each sample was measured to find the acidic or basic nature of the dye-contaminated wastewater and overall presence of total soluble salts. The $\mathrm{pH}$ and TDS were analyzed by Multimeter (Crison MM-40+). COD of wastewater was measured by using the open reflux method (APHA, AWWA, WEF, 1999).

\section{HPLC Analysis}

Residues of 4-nitroaniline were analyzed using HPLC (Shimadzu CLASS-VP V6.13 SP1). HPLC analysis was performed using a $\mathrm{C} 18$ reverse phase column. The mobile phase was operated at rate of $1 \mathrm{~mL} \mathrm{~min}{ }^{-1}$ with 40:60 ratio of methanol to water $(\mathrm{v} / \mathrm{v})$. The injection volume was $20 \mu \mathrm{L}$ per sample. The oven temperature was set at $40^{\circ} \mathrm{C}$. To determine the biodegradation of 4-nitroaniline, $1.5 \mathrm{~mL}$ liquid volume was taken from each vial and then solution was centrifuged at $10,000 \mathrm{rpm}$ for $15 \mathrm{~min}$. After centrifugation, the residues of 4-nitroaniline in supernatant were analyzed by HPLC. Elution of the molecules was analyzed at $254 \mathrm{~nm}$ by using UV detector. Standard solution of 4-nitroaniline was run at different concentrations $(0-100$ $\mu$ mol L ${ }^{-1}$ ) on HPLC to draw a standard curve. The samples were compared with standards.

\section{Isolation of Bacterial Strains through Enrichment Technique}

For the isolation of bacterial strains from dyecontaminated wastewater and sludge, suspension was first prepared in $250 \mathrm{~mL}$ conical flasks containing mineral salt medium (MSM) and 4-nitroaniline $\left(100 \mu \mathrm{mol} \mathrm{L}^{-1}\right)$ as a source of carbon and nitrogen. Similarly, suspensions in MSM were prepared using $100 \mu \mathrm{mol} \mathrm{L}^{-1}$ 4-nitroaniline and different types of dyes at $100 \mathrm{mg} \mathrm{L}^{-1}$ concentration. The suspension in conical flasks was inoculated with 10 $\mathrm{mL}$ of wastewater or equivalent amount of sludge. For each sample, the suspension was prepared in a separate conical flask. Flasks containing the suspension was covered and incubated for seven days at $35^{\circ} \mathrm{C}$ in a shaking incubator at $180 \mathrm{rpm}$. Degradation rate was measured by centrifugation of the culture of each suspension at 10,000 rpm for $15 \mathrm{~min}$ to remove cells. Supernatants were run on HPLC to check the biodegradation of aromatic amine (4niroaninline). After seven days of incubation, $1 \mathrm{~mL}$ culture suspension was spread on agar plate using dilute plate technique. For this purpose, ten dilutions $\left(10^{-1}-10^{-10}\right)$ were prepared and last three dilutions were spread on agar medium. Bacterial colonies showing prolific growth on the medium were selected and these bacterial colonies were used to obtain pure cultures by streaking then on fresh agar medium. This process was repeated twice. A total of 256 isolates were selected: 173 isolated by using 4-nitroaniline as source of $\mathrm{C}$ and $\mathrm{N}$, while 83 on the basis of 4-nitroaniline plus dyes.

\section{Screening of Efficient Bacterial Strains Capable of Degrading 4-nitroaniline}

A total of 256 purified bacterial isolates which were finally obtained after purification were further subjected to screening to acquire the efficient strains capable of degrading aromatic amines. 


\section{Screening on the Basis of Bacterial Cell Biomass}

Cell biomass was calculated to determine the ability of bacterial isolates to grow efficiently in MSM containing 4nitroaniline. The vial containing $2 \mathrm{~mL}$ MSM along with 4nitroaniline was inoculated with $0.5 \mathrm{~mL}$ bacterial isolates and incubated at $35^{\circ} \mathrm{C}$ for $48 \mathrm{~h}$. Biomass increase was calculated at different time intervals.

\section{Screening on the Basis of Biodegradation of 4- Nitronailine in Liquid Medium}

For the selection of efficient strains, all selected bacterial isolates were grown in glass vials containing $2 \mathrm{~mL}$ MSM broth having $100 \mu \mathrm{mol} \mathrm{L} \mathrm{L}^{-1}$ of 4-nitroaniline. The solution was inoculated by selected bacterial isolates with the help of sterilized tooth picks. These vials were sealed and incubation was done at $35^{\circ} \mathrm{C}$ for $24 \mathrm{~h}$ in a shaking incubator at $180 \mathrm{rpm}$ to give aerobic conditions. After HPLC analysis, 18 isolates showing highest degradation of 4-nitroanailine were selected. Based on cell biomass and 4-nitroanailine degradation rate, most efficient bacterial strain IL11 was identified.

\section{Identification of Selected Bacterial Strains}

Most efficient bacterial isolate IL11 was identified by $16 \mathrm{~S}$ rRNA gene analysis. To identify the bacterial strain, nearly complete 16S rRNA gene was amplified by the PCR using forward and reverse primers, 9F (5'-GAGTTTGATC CTGGCTCAG-3') and 1510R (5'-GGCTACCTTGT TACGA- $3^{\prime}$ ). The PCR products were purified using PCR purification kit and sequenced using the BigDyeTM Terminator Cycle Sequencing Kits following the manufacturer's protocols (ABI PRISM ${ }^{\circledR} 3730$ XL Genetic Analyzer). BioEdit software package was used to obtain the consensus sequence. Sequences of closely related type strains, used for constructing the phylogenetic tree, were selected and retrieved from the National Center for Biotechnology Information and DNA Data Bank of Japan databases by BLAST searches for bacteria. The sequence of the bacterial strain IL11was deposited in GenBank under the accession member KT361501 (Fig. 1).

\section{Statistical Analysis}

All experiments were conducted in three replications per treatment in order to secure reproducibility of the results and to ensure clear accounting of all experimental results over time and space. The average size of the data values was calculated by the arithmetic means. The mean variability of the data values was determined by calculating the standard error. The statistical difference among means of wastewater collected samples was calculated through ANOVA and Fisher's LSD was used to analyze difference between the treatments using MSTAT software.

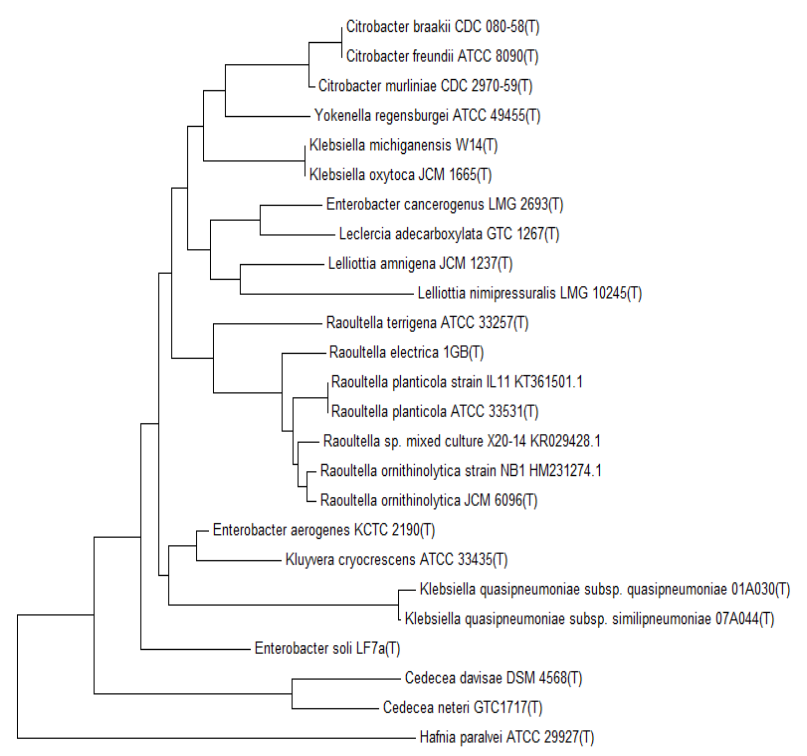

Fig. 1: Phylogenetic tree of bacterial strain IL11 (KT361501) with closely resembled species of the genus Raoultella inferred from 16S rRNA gene sequences

\section{Results}

\section{Analysis of Wastewater and Sludge}

The wastewater and sludge samples collected from textile wastewater streams were analyzed for physical and chemical characteristics. The results showed a wide variation in selected physical and chemical parameters (Table 1). The $\mathrm{pH}$ range was between 8.10 and 12.3 in different wastewater samples obtained from different textile industries. Four samples (AP, IL, MP and RT) showed significant different $\mathrm{pH}$ from each other and from all other collected samples $(\mathrm{P}<0.05)$. Maximum $\mathrm{pH}$ was recorded in case of wastewater sample collected from one of the industries (MP) of Faisalabad. Similarly, a wide variation was observed in TDS (500-20100 $\mathrm{mg} \mathrm{L}^{-1}$ ) of different wastewater samples. Maximum TDS were found in the same sample (MP Faisalabad) in which $\mathrm{pH}$ was also high. All the collected wastewater samples were significantly different for TDS $(\mathrm{P}<0.05)$. Wastewater of most of textile industry was highly colored and spectrophotometer analysis showed the different range of color intensity varying between $0.12-1.92$ at $600 \mathrm{~nm}$. Wastewater collected from (MP, AP, FT and RT) showed significantly different absorbance range $(\mathrm{P}<0.05)$. The color intensity of the wastewater sample collected from the district of Faisalabad was found to be very high and showed an absorbance up to 1.92 at $600 \mathrm{~nm}$. The same sample (MP) also showed high COD values $\left(556 \mathrm{mg} \mathrm{L}^{-1}\right)$. In general, COD range was observed from 125 to $556 \mathrm{mg} \mathrm{L}^{-1}$. All collected wastewater samples showed significantly different COD except wastewater samples of AT, FT, KT and KTD which were non-significantly different from each other $(\mathrm{P}>0.05)$. 
Kausar et al. / Int. J. Agric. Biol., Vol. 18, No. 6, 2016

Table 1: Physico-chemical analysis of dye wastewater collected from different sites

\begin{tabular}{llllll}
\hline Sampling source and wastewater type & $\mathrm{pH}$ & TDS $\left(\mathrm{mg} \mathrm{L}^{-1}\right)$ & $\mathrm{COD}\left(\mathrm{mg} \mathrm{L}^{-1}\right)$ & Absorbance at $600 \mathrm{~nm}$ \\
\cline { 2 - 5 } & & Mean \pm SE & Mean \pm SE & Mean \pm SE & Mean \pm SE \\
\hline Faisalabad & AP (effluent/wastewater) & $10.2 \pm 0.058 \mathrm{~b}$ & $12240 \pm 5.12 \mathrm{c}$ & $512.22 \pm 2.2 \mathrm{~b}$ & $1.22 \pm 0.003 \mathrm{~b}$ \\
& PD (Effluent/wastewater) & $8.48 \pm 0.012 \mathrm{def}$ & $2840 \pm 3.2 \mathrm{f}$ & $350.1 \pm 2.1 \mathrm{c}$ & $0.18 \pm 0.005 \mathrm{fg}$ \\
& IL (Effluent/wastewater) & $8.78 \pm 0.017 \mathrm{c}$ & $3220 \pm 4.0 \mathrm{~d}$ & $301.10 \pm 1.7 \mathrm{~d}$ & $0.12 \pm 0.001 \mathrm{~g}$ \\
& AT (Sludge ) & $8.31 \pm 0.015 \mathrm{fg}$ & $2140 \pm 3.1 \mathrm{~h}$ & $250.12 \pm 2.9 \mathrm{f}$ & $0.31 \pm 0.002 \mathrm{e}$ \\
& MP (Effluent/wastewater) & $12.3 \pm 0.09 \mathrm{a}$ & $20100 \pm 4.2 \mathrm{a}$ & $556.09 \pm 3.6 \mathrm{a}$ & $1.92 \pm 0.002 \mathrm{a}$ \\
Sheikhupura & FT (Sludge) & $8.32 \pm 0.013 \mathrm{efg}$ & $2860 \pm 2.3 \mathrm{e}$ & $245.11 \pm 2.1 \mathrm{f}$ & $0.52 \pm 0.001 \mathrm{c}$ \\
& RT (Sludge) & $8.10 \pm 0.071 \mathrm{~g}$ & $2210 \pm 4.4 \mathrm{~g}$ & $265.31 \pm 2.4 \mathrm{e}$ & $0.45 \pm 0.003 \mathrm{~d}$ \\
& BT (Effluent/wastewater ) & $8.32 \pm 0.023 \mathrm{efg}$ & $500 \pm 1.5 \mathrm{j}$ & $125.12 \pm 7.5 \mathrm{~h}$ & $0.25 \pm 0.001 \mathrm{e}$ \\
Rawalpindi & KT (Effluent/wastewater) & $8.56 \pm 0.012 \mathrm{cde}$ & $1350 \pm 2.3 \mathrm{i}$ & $145.19 \pm 1.8 \mathrm{~g}$ & $0.19 \pm 0.001 \mathrm{f}$ \\
& KTD(Effluent/wastewater) & $8.67 \pm 0.012 \mathrm{~cd}$ & $13000 \pm 2.4 \mathrm{~b}$ & $150.28 \pm 3.9 \mathrm{~g}$ & $0.16 \pm 0.001 \mathrm{fg}$ \\
& Range & $8.10-12.3$ & $500-20100$ & $125-556$ & $0.12-1.92$ \\
\hline
\end{tabular}

Values sharing same letters in each column differ non significantly $(\mathrm{P}>0.05)$

Table 2: Bacterial strains isolated through enrichment of MSM with 4-nitroaniline as a source of carbon and nitrogen

\begin{tabular}{lll}
\hline Sampling source and wastewater type & No. of bacterial isolates \\
\hline Faisalabad & AP (effluent) & AP1-AP18 \\
& PD (Effluent) & PD1-PD18 \\
& IL (Fresh effluent ) & IL1-IL26 \\
& AT (Sludge ) & AT1-AT15 \\
Sheikhupura & MP (Effluent) & MP1-MP16 \\
& FT (Sludge ) & FT1-FT15 \\
& RT (Sludge) & RT1-RT18 \\
Rawalpindi & BT (Effluent ) & BT1-BT17 \\
& KT (Fresh Effluent) & KT1-KT15 \\
& KTD(Drain WW) & KTD1-KTD15 \\
\hline
\end{tabular}

Total 173 bacterial isolates obtained through enrichment of 4-nitroaniline. Concentration of 4-nitroaniline was $100 \mu \mathrm{mol} \mathrm{L}^{-1}$

\section{Isolation and Screening of Bacteria Capable of Degrading Aromatic Compounds}

A total of 256 bacterial strains were isolated from textile wastewater/sludge through the enrichment technique. About 173 isolates were obtained by enriching MSM with 4-nitroaniline (Table 2). About half of the above (93) strains were obtained from the wastewater samples of Faisalabad, 50 strains from wastewater of Sheikhupura and 30 from the textile industry of Rawalpindi. Eighty three bacterial isolates were obtained using different dyes with 4-nitroaniline as a source of carbon and nitrogen (Table 3). These bacterial strains showed varying potential to degrade 4nitroaniline in broth media under shaking (aerobic) conditions. Of total bacterial isolates, approximately $7 \%$ isolates were more efficient than rest of strains and capable of degrading $>75 \%$ 4-nitroaniline after $24 \mathrm{~h}$ under aerobic conditions. The remaining isolates showed either medium $(50-75 \%)$ or low $(<50 \%)$ potential for degradation of 4 nitroaniline (Table 4$)$.

After the initial screening, 18 bacterial isolates were tested for their potential to degrade 4-nitroaniline in liquid MSM and their ability to grow (cell biomass) on MSM in the presence of 4-nitroaniline. Three strains (IL11, KT1 and PD1) were highly effective in degrading 4-nitroaniline and gaining increase in cell biomass over the period of time (Table 5). Bacterial strain IL11 completely (100\%) degraded $100 \mu \mathrm{mol}$ 4-nitroaniline in liquid MSM under aerobic conditions after $72 \mathrm{~h}$ of incubation, while the cell biomass of this strain was $0.69 \mathrm{mg} \mathrm{L}^{-1}$ after $72 \mathrm{~h}$ under similar condition. KT1 strain was able to degrade $95 \%$ of the spiked 4nitroaniline with the cell biomass of $0.65 \mathrm{mg} \mathrm{L}^{-1}$ after $72 \mathrm{~h}$ in liquid MSM. For strain PD1, degradation rate was $90 \%$ with the cell biomass of $0.61 \mathrm{mg} \mathrm{L}^{-1}$ under similar conditions. Degradation rates for the rest of 15 bacterial isolates were in the range of $70-85 \%$. After 16S rRNA gene sequencing, it was confirmed that most efficient strain IL11 showed highest resemblance to the species of the genus Raoultella.

\section{Discussion}

This study demonstrated that the $\mathrm{pH}$, TDS and COD values of wastewater released from the textile industry were substantially higher than the permissible limits set by NEQS (2000). Different kinds of salts are used in huge quantities in the textile industry. As a result, a large amount of sodium and chloride ions are present in textile wastewater, which increases the toxicity of water sources (Ali et al., 2006; Paul et al., 2012; Dey and Islam, 2015). The color of the effluent measured as absorbance was highly visible, which may have environmental concerns including aesthetic problems (Sun et al., 2009; Modi et al., 2010; Lu et al., 2010; Holkar et al., 2016).

In order to obtain bacterial strains capable of degrading dye-originated aromatic compounds, several bacterial strains were isolated from the dye-contaminated wastewater/sludge through the MSM enrichment with 4nitroaniline and different groups of dyes. Most efficient bacterial strain obtained through the enrichment of 4nitroaniline was identified by $16 \mathrm{~S}$ rRNA gene analysis as Raoultella planticola (IL11). This strain was very effective and complete (100\%) degradation of $100 \mu \mathrm{mol}$ $\mathrm{L}^{-1}$ of 4-nitroaniline was accomplished in $72 \mathrm{~h}$ of incubation with stirring (aerobic) conditions. Previously, a few species of bacteria capable of degrading dye-related aromatic compounds were reported (Khalid et al., 2008; 
Table 3: Bacterial strains isolated through enrichment of MSM with 4-nitroaniline plus dyes as source of carbon and nitrogen

\begin{tabular}{lll}
\hline Sample source used & Dye used & No. of bacterial isolates \\
\hline FT & Reactive Black-5 & FTR1-FTR10 \\
FT & Reactive Blue-BRS & FTB1-FTB12 \\
FT & Direct Blue & D1-D15 \\
PD & Reactive Black-5, Reactive Blue-BRS, Direct Blue & PDR1-PDR12 \\
PD & Reactive Black-5, Reactive Blue-, BRS, Disperse Yellow, Direct Blue & PDB1-PDB12 \\
KT & Reactive Black-5, Reactive Blue- BRS, Direct Blue & KTR1-KTR12 \\
KTD & Reactive Black-5, Reactive Blue-BRS, Disperse Yellow, Direct Blue & KTB1-KTB10 \\
\hline
\end{tabular}

Total 83 bacterial isolates obtained through enrichment of 4-nitroaniline and different of dyes (individually as well as in group). Concentration of dye was $100 \mathrm{mg} \mathrm{L}^{-1}$ 4-nitroaniline concentration was $100 \mu \mathrm{mol} \mathrm{L}^{-1}$

Table 4: Bacterial isolates exhibiting different potential to degrade 4-nitroaniline in liquid medium

\begin{tabular}{ll}
\hline Degradation $\%$ & No of bacterial isolates \\
\hline High degradation $>75 \%$ & $18(7.03 \%)$ \\
Medium degradation $50-75 \%$ & $120(46.8 \%)$ \\
Low degradation $<50 \%$ & $118(46.09) \%$ \\
Total isolates & 256 \\
\hline
\end{tabular}

Table 5: Bacterial isolates capable of degrading 4nitroaniline in liquid medium after $72 \mathrm{~h}$

\begin{tabular}{lll}
\hline Bacterial isolate & Degradation $(\%)$ & Biomass gain $\left(\mathrm{mg} \mathrm{L}^{-1}\right)$ \\
\hline AP10 & $80 \pm 2.21$ & $0.65 \pm 0.02$ \\
AP15 & $81 \pm 1.23$ & $0.38 \pm 0.01$ \\
PD4 & $60 \pm 2.22$ & $0.23 \pm 0.004$ \\
PD9 & $70 \pm 2.50$ & $0.31 \pm 0.01$ \\
IL5 & $75 \pm 1.31$ & $0.24 \pm 0.08$ \\
IL7 & $72 \pm 2.70$ & $0.32 \pm 0.12$ \\
IL11 & $\mathbf{1 0 0} \pm \mathbf{0 . 0 0}$ & $\mathbf{0 . 6 9} \pm \mathbf{0 . 0 6}$ \\
MP10 & $78 \pm 2.22$ & $0.42 \pm 0.03$ \\
MP37 & $85 \pm 2.22$ & $0.61 \pm 0.04$ \\
KT1 & $95 \pm 1.11$ & $0.75 \pm 0.13$ \\
KT3 & $72 \pm 2.22$ & $0.55 \pm 0.27$ \\
KT6 & $70 \pm 2.01$ & $0.42 \pm 0.12$ \\
KT9 & $76 \pm 1.21$ & $0.50 \pm 0.19$ \\
PD1 & $90 \pm 1.29$ & $0.71 \pm 0.07$ \\
PD4 & $75 \pm 2.11$ & $0.51 \pm 0.09$ \\
PD9 & $78 \pm 1.22$ & $0.45 \pm 0.12$ \\
D1 & $75 \pm 2.22$ & $0.50 \pm 0.12$ \\
D5 & $90 \pm 1.10$ & $0.67 \pm 0.11$
\end{tabular}

Data is shown as means \pm SE of three replicates

Garg et al., 2012; Agrawal et al., 2013). Microbial degradation provides most promising possibility for complete mineralization of dyes and intermediates (aromatic amines), due to greater adaptability and increased rate of bacterial growth (Saratale et al., 2011; Singh et al., 2015). Reduction of azo bonds in anaerobic condition is the first step in the breakdown of azo dyes, forming aromatic amines (Pandey et al., 2007; Franciscon et al., 2009). The intermediate products of first step (decolorization process) are degraded by various bacterial enzymes such as hydroxylase and oxygenase (Pandey et al., 2007; Khalid et al., 2009). Furthermore, the selected bacterial strain has the ability to cleave $-\mathrm{N}=\mathrm{N}-$ bond, probably with the aid of azoreductase enzyme (McMullan et al., 2001; Khalid et al., 2010).

\section{Conclusion}

Textile wastewater is highly polluted and its treatment is a complex process. The isolated bacterial strain, $R$. planticola (IL11), showed great potential to degrade dye-associated aromatic amine (4-nitroaniline). This bacterium could be used in combination with dye-degrading strains for bioremediation of textile industrial wastewater.

\section{Acknowledgment}

Authors acknowledge financial support for this study from Higher Education Commission Islamabad under Indigenous Ph.D. Fellowship Program and research grant from Pakistan Science Foundation under NSLP.

\section{References}

Agrawal, S., D. Tipre, B. Patel and S. Dave, 2013. Optimization of triazo Acid Black 210 dye degradation by Providencia sp. SRS82 and elucidation of degradation pathway. Process Biochem., 49: 110-119

Ali, S., R. Nadeem, H.N. Bhatti, S. Hayat, S. Ali, S. Chatha and M. Muneer, 2006. Analyses and treatment of textile effluents. Int. J. Agric. Biol., 8: 641-644

Andleeb, S., N. Atiq, M.I. Ali, R.R. Hussnain, M. Shafiqe and B. Ahmed, 2010. Biological treatment of textile effluent in stirred tank bioreactor. Int. J. Agric. Biol., 12: 256-260

Annuar, M.S.M., S. Adnan, S. Vikineswary and Y. Chisti, 2009. Kinetics and energitics of azo dye decolorization by Pycnoporus sanguineus. Water Air Soil Pollut., 202: 179-188

APHA, AWWA, WEF, 1999. Standard Methods for the Examination of Water and Wastewater (Methods: 5220 C. Closed Reflux Titrimetric Method)

Aravind, P., H. Selvara, S. Ferro and M. Sundaram, 2016. An integrated (electro- and bio-oxidation) approach for remediation of industrial wastewater containing azo-dyes: Understanding the degradation mechanism and toxicity assessment. J. Haz. Mat., 318: 203-215

Bezerra, D.S.A., 2005. Reductive Decolourisation of dyes by thermophilic anaerobic granular sludge. Ph. D. Thesis, University of Wageningen, The Netherlands

Bomhard, E.M. and B. Herbold, 2005. Genotoxic activities of aniline and its metabolites and their relationship to the carcinogenicity of aniline in the spleen of rats. Crit. Rev. Toxicol., 35: 783-835

Chung, K.T., J.S. Stevens and C.E. Cerniglia, 1992. The reduction of azo dyes by the intestinal microflora. Crit. Rev. Microbiol., 18: 175-190

Dey, S. and A. Islam, 2015. A Review on Textile Wastewater Characterization in Bangladesh. Resour. Environ. 5: 15-44

Franciscon, E., A. Zille, L.R. Durrant, G.F. Fantinatti and A.C. Paulo, 2009. Microaerophilic-aerobic sequential decolourization/biodegradation of textile azo dyes by a facultative Klebsiella sp. Strain VN-31. Process Biochem., 44: 446-452 
Garg, S.K., M. Tripathi, S.K. Singh and J.K. Tiwari, 2012. Biodecolorization of textile dye effluent by Pseudomonas putida SKG-1 (MTCC10510) under the conditions optimized for monoazo dye orange II color removal in simulated minimal salt medium. Int. Biodeter. Biodegr., 74: 24-35

Holkar, C.R., A.J. Jadhav, D.V. Pinjari, N.M. Mahamuni and A.B. Pandit, 2016. A critical review on textile wastewater treatments: Possible approaches. J. Environ. Manage., 182: 351-366

Kangwansupamonkon, K.W., W. Jitbunpot and S. Kiatkamjornwong, 2010. Photocatalytic efficiency of $\mathrm{TiO}_{2} /$ poly [acrylamide-co-(acrylic acid)] composite for textile dye degradation. Polym. Degrad. Stability, 95: 1894-1902

Khalid, A., M. Arshad and D. Crowley, 2010. Bioaugmentation of azo dyes. In: The Hand Book of Environment Chemistry, pp: 1-37. Erkurt, H.A. (ed.). Springer Springer-Verlag, Berlin, Germany

Khalid, A., M. Arshad and D.E. Crowley, 2008. Decolorization of azo dyes by Shewanella sp. Under saline conditions. Appl. Microbiol. Biotechnol., 79: 1053-1059

Khalid, A., M. Arshad and D.E. Crowley, 2009. Biodegradation potential of pure and mixed bacterial cultures for removal of 4-nitroanaline from textile dye wastewater. Water Res., 43: 1110-1116

Khalid, A., S. Batool, M.T. Siddique, Z.H. Nazli, R. Bibi, S. Mahmood and M. Arshad, 2011. Decolorization of Remazol Black-B azo dye in soil by fungi. Soil Environ., 30: 1-6

Kurade, M.B., T.R. Waghmode, S.M. Patil, B.H. Jeon and S.P. Govindwar, 2016. Monitoring the gradual biodegradation of dyes in a simulated textile effluent and development of a novel triple layered fixed bed reactor using a bacterium-yeast consortium. Chem. Eng. J., In press

Lu, H., J. Zhou, J. Wang, W. Si, H. Teng and G. Liu, 2010. Enhanced biodecolorization of azo dyes by anthraquinone-2-sulfonate immobilized covalently in polyurethane foam. Bioresour. Technol., 101: 7185-7188

Mahmood, S. M. Arshad, A. Khalid, Z.H. Nazli and T. Mahmood, 2011. Isolation and screening of azo dye decolorizing bacterial isolates from dye-contaminated textile wastewater. Soil Environ., 30: 7-12

McMullan, G., C. Meehan, A. Conneely, N. Kirby, T. Robinson, P. Nigam, I.M. Banat, R. Marchant and W.F. Smyth, 2001. Microbial decolourisation and degradation of textile dyes. Appl. Microbiol. Biotechnol., 56: 81-87

Meng, X., G. Liu, J. Zhou, Q.S. Fu and G. Wang, 2012. Azo dye decolorization by Shewanella aquimarina under saline conditions. Bioresour. Technol., 114: 95-101

Modi, H.A., G. Rajput and C. Ambasana, 2010. Decolorization of water soluble azo dyes by bacterial cultures, isolated from dye house effluent. Bioresour. Technol., 101: 6580-6583
NEQS, 2000. National Environmental Quality Standards for Municipal and Liquid Industrial Effluents. Available at: http://www.cpi.org.pk/Local_legislation/rneqs.pdf. (Accessed: 20 May 2015)

Pandey, A., P. Singh and L. Lyengar, 2007. Bacterial decolorization and degradation of azo dyes. Int. Biodeter. Diodegr., 59: 73-84

Paul, S.A., S.K. Chavan and S.D. Khambe, 2012. Studies on characterization of textile industrial waste water in solapur city. Int J. Chem. Sci., 10: 635-642

Peyton, B.M., T. Wilson and D.R. Yonge, 2002. Kinetics of phenol biodegradation in high salt solutions. Water Res., 36: 4811-4820

Pourbabaee, A.A., F. Malekzadeh, M.N. Sarbolouki and F. Najafi, 2006. Aerobic decolorization and detoxification of a disperse dye in textile effluent by a new isolate of Bacillus sp. Biotechnol. Bioeng., 93: 631-635

Rawat, D., V. Mishra and R.S. Sharma, 2016. Detoxification of azo dyes in the context of environmental processes. Chemosphere, 155: 591-605

Saratale, R.G., G.D. Saratale, J.S. Chang and S.P. Govindwar, 2011 Bacterial decolorization and degradation of azo dyes: A review. $J$. Taiwan Inst. Chem. Engin., 42: 138-157

Seesuriyachan, P., S. Takenaka, A. Kuntiya, S. Klayraung, S. Murakmi and K. Aoki, 2007. Metabolism of azo dyes by Lactobacillus caesi TISTR 1500 and effects of various factors on decolorization. Water Res., 41: 985-989

Singh, R.L., P.K. Singh and R.P. Singh, 2015. Enzymatic decolorization and degradation of azo dyes-A review. Int. biodeter. Biodegr., 104 21-31

Sun, J.H., S.P. Sun, G.L. Wang and L. Qiao, 2009. Degradation of azo dye Amido black 10B in aqueous solution by Fenton oxidation process. Dyes Pigm., 74: 647-652

Verma, P. and D. Madamwar, 2002. Comparative study of transformation of azo dye by different white rot fungi. Ind. J. Biotechnol., 1: 393396

Wu, X., S. Kannan, V. M. Ramanujam and M.F. Khan, 2005. Iron release and oxidative DNA damage in splenic toxicity of aniline. J. Toxicol. Environ. Health, 68: 657-666

Xu, H., T.M. Heinze, S. Chen, C.E. Cerniglia and H. Chen, 2007. Anaerobic metabolism of 1-amino-2-naphthol-based azo dyes (Sudan dyes) by human intestinal microflora. Appl. Environ. Microbiol., 73: 7759-7762

(Received 03 September 2016; Accepted 10 September 2016) 